\title{
Influence of intervention on the menu's nutritional and sensory qualities and on the food waste of children's education center
}

\author{
Influência da intervenção na qualidade nutricional e sensorial \\ de cardápios e resto-ingestão de centro de educação infantil
}

Vanessa Rocha de Souza ${ }^{1}$

Amanda Brinco Ferreira ${ }^{1}$

Jackline Freitas Brilhante de São José ${ }^{1}$

Erika Madeira Moreira da Silva ${ }^{1}$

Daniela Alves Silva ${ }^{1}$

${ }^{1}$ Centro de Ciências da Saúde, Universidade Federal do Espírito Santo. Av. Marechal Campos 1468, Maruípe. 29043-910 Vitória ES Brasil.vanessas.rocha@ yahoo.com.br

\begin{abstract}
The aim was to evaluate the influence of an intervention on the nutritional and sensory quality of the menus and on the food waste of a Children's Educational Center. It is a quasi-experimental study that used the Qualitative Assessment of the Menu Preparations method and performed the waste-ingestion quantities and clean leftovers. The intervention was characterized by the inclusion of new recipes and adequacy of portions according to recommendations for the children's age group. Data were analyzed using the Mann Whitney test with a significance level of $p<0.05$. The intervention resulted in a reduction in the occurrence of the side dish supply, color monotony, presence of sweets, presence of fried foods, sweets associated with fried foods, and repetition of the main dish cooking technique. In addition, there was a significant reduction in the average quantities of waste-ingestion/child (from $69.02 \pm$ $11.87 \mathrm{~g}$ to $37.06 \pm 15.57 \mathrm{~g})$, clean leftovers /child (from $161.47 \pm 44.12 \mathrm{~g}$ to $35.23 \pm 33.73 \mathrm{~g}$ ) and clean leftovers percentage (from $39.56 \pm 7.96$ to $21.01 \pm 17.15)$. The positive influence of intervention reinforces the importance of adjustments in recipes and portioning of preparations to meet the nutritional recommendations and to control food waste.
\end{abstract}

Key words School feeding, Food quality, Intervention studies
Resumo O objetivo do estudo foi avaliar a influência de uma intervenção na qualidade dos cardápios e no desperdício de alimentos em um Centro de Educação Infantil. Trata-se de um estudo quase-experimental que utilizou o método de Avaliação Qualitativa de Preparações de Cardápios e avaliou quantidades de resto-ingestão e sobra limpa. A intervenção foi caracterizada pela inclusão de receituários e adequação do porcionamento das preparações segundo recomendações para a faixa etária. Os dados foram analisados pelo teste de Mann Whitney, nível de significância de $p<0,05$. A intervenção proporcionou redução na ocorrência de oferta de guarnição, monotonia de cores, presença de doce, presença de frituras e de doce associado a fritura e repetição da técnica de cocção do prato principal. Além disso, observou-se redução significativa nas quantidades médias de resto-ingestão/criança (de 69,02 $\pm 11,87 \mathrm{~g}$ para 37,06 $\pm 15,57 \mathrm{~g}$ ), de sobra limpa/criança (de 161,47 $\pm 44,12 \mathrm{~g}$ para $35,23 \pm 33,73 \mathrm{~g}$ ) e do percentual de sobra limpa (de 39,55 \pm 7,96 para $21,01 \pm 17,15)$. A influência positiva da intervenção reforça a importância de adequações nos receituários e no porcionamento, para o atendimento das recomendações nutricionais e controle do desperdício de alimentos no ambiente escolar. Palavras-chave Alimentação escolar, Qualidade dos alimentos, Estudos de intervenção 


\section{Introduction}

Proper children's growth and development are proven to be related to eating quality food and in quantities that meet the energy and nutritional recommendations for this stage of life ${ }^{1}$. But the fulfillment of these needs will be met only if the childhood characteristics are considered ${ }^{2}$.

This is a period of training in eating habits and the environment plays a role of utmost importance ${ }^{2,3}$. As result of the preschool children's curiosity for discovery of olfactory, tactile and taste sensations, it is important to diversify the supply of food for children given that it may assist in the formation of healthy eating habits ${ }^{2}$.

Availability, variety, form of preparation and presentation of food are some of the factors that may influence the choices and food consumption by children in all environments in which they operate.

However, for food to contribute to the proper state of health, it needs to be known and/or accepted by the individual in his/her social environment, and taking into consideration only the nutritional quality is not enough ${ }^{3}$. In this sense, schools are a privileged environment to promote the diffusion of appropriate eating habits ${ }^{1,4}$.

In Brazil, school meals are a right of base public education students, and states have the duty to enforce it. Thus, the National School Meal Program (Programa Nacional de Alimentação Escolar - PNAE) was implemented in the 50's and has the proper planning of menus among its objectives, considering the nutritional and sensory characteristics of the preparations, with color articulation, and the food nutritional, qualitative and harmony adequacies 5 .

Since the menu quality is the focus of this study, it is noteworthy that among the Brazilian methodologies used for this purpose, the Qualitative Assessment of Menu Preparations (Avaliação Qualitativa de Preparações de Cardápios - AQPC) is a tool that assists in the development of appropriate menus from the nutritional and sensory points of view 6 .

Moreover, the evaluation of the waste-ingestion is also an important indicator on the acceptance of the menu and the production control. This assessment consists in wheighing the total amount of food placed in the plate that has not been consumed, and the evaluation of the clean leftovers, which is the amount of preparations that were produced, but were not served ${ }^{4}$.

Given the above, the study aimed to evaluate the influence of the intervention on nutritional and sensory qualities of the menu and on the food waste control in a Brazilian Children's Education Center.

\section{Material and methods}

\section{Study Design}

This is a quasi-experimental study, before and after ${ }^{7}$, performed in a Children's Educational Center (Centro de Educação Infantil - CEI) selected by convenience. The CEI is linked to a Brazilian public institution of education, located in the capital of Espírito Santo. This instit An intervention proposal to improve the nutritional and sensory qualities of the menu offered by the CEI was assessed.

The CEI assists children of teachers and civil servants and it offers 45 vacancies for children from 1 to 5 years of age, that run part-time from Monday to Friday. During the morning when the children remained in the CEI, the following meals were offered: morning snack $(8 \mathrm{am})$ and lunch $(10: 30 \mathrm{am})$. It is noteworthy that the morning snack sent from home by their parents and three times for week this foods could be fruits. The CEI offers lunch according to food availability from public educational institution.

\section{Menu evaluation}

The menus offered by the CEI were evaluated in a 30-day period divided into two phases: 15 consecutive weekdays in September 2013 (before the intervention) and 15 consecutive weekdays in October/November 2014 (after the intervention). Data were collected by eight graduate nutrition students.

The Avaliação Qualitativa de Preparações de Cardápios (AQPC) method was used ${ }^{6}$, adapted to the local conditions. The frequency of occurrence of the criteria expressed as percentage, considering the percentage adequacy of each item in relation the total days evaluated (15 days). The items were: main dish cooking techniques, colours of the preparations, presence of fruits, presence of sweets, presence of frieds foods, presence of sweets and frieds foods, foods rich in sulfur, leafy vegetables and vegetables (Chart 1).

The quantification of the Waste-Ingestion (WI) and Clean Leftovers (CL) was also performed. The scale, brand Filizola, with a 50 kilogram capacity and a 0.1 kilogram precision was used to all weights. The WI and CL was collected in plastic bags. 
Chart 1. Qualitative Assessment of the Menu Preparations method (Avaliação Qualitativa de Preparações do Cardápio - $A Q P C)$, adapted from Veiros and Proença (2003).

\begin{tabular}{|l|l|}
\hline \multicolumn{1}{|c|}{ Criteria } & \multicolumn{1}{c|}{ Description } \\
\hline Main Dish Cooking Techniques & Cooking techniques: stew, baked, cooked and raw. \\
\hline Colors of the Preparations & Presence of two or more preparations with the same color. \\
\hline Presence of Fruits & When offered fresh as dessert. \\
\hline Presence of Sweets & Considering industrialized desserts, such as gelatin or candies. \\
\hline Presence of Fried Foods & Considering the frying technique (deep frying or shallow frying). \\
\hline Presence of Sweets and Fried Foods & When the supply of both occurred on the same day. \\
\hline Foods Rich in Sulfur & $\begin{array}{l}\text { Disregarding beans, the presence of two or more in a single day. They } \\
\text { were: garlic, onions, cauliflower, peas, beans, apples, watermelon, corn, } \\
\text { egg, cabbage. }\end{array}$ \\
\hline Leafy Vegetables & Chard, Collard Greens, White Cabbage, Red Cabbage, Lettuce. \\
\hline Vegetables & $\begin{array}{l}\text { Group A (Zucchini Squash, Cauliflower, Bell Peppers, Tomato, Onion). } \\
\text { Group B (Pumpkin, Beets, Carrots, Chayote Squash, Green Beans). } \\
\text { Group C (Russet Potatoes, Yam) }\end{array}$ \\
\hline
\end{tabular}

${ }^{a}$ Vegetables classified according to quantities carbohydrate: group A - countain about five percent, group B - countain about ten percent, and group $\mathrm{C}$ - countain about twenty percent ${ }^{8}$.

The WI was estimated by weighing all the food left on plates by the children, excluding peels, bones, seeds and marc. A control of the number of children who had lunch was done daily. Thus, the average per child WI amount was estimated by the following equation: waste-ingestion per child $(\mathrm{kg})=$ weight of the total waste / number of children. Besides, the percent waste-ingestion (\%WI) was calculated by the relationship between the weight of the plate waste and weight of the distributed meal and multiplied by one hundred ${ }^{4}$.

The CL were obtained by weighing the amount of uneaten food, subtracting the weight of the containers in which the preparations were accomodated. Thus, the average per child clean leftovers amount was estimated by the following equation: clean leftovers per child $(\mathrm{kg})=$ weight of the clean leftovers total/ number of children. Besides, the percent clean leftovers (\%CL) was calculated by the relationship between the weight of the clean leftovers and weight of the produced meal and multiplied by one hundred'.

\section{Intervention}

The intervention consisted of two phases: planning menus and food handlers training with implementation of the planned menus. The first phase was done in a week (10/20/2014 to $10 / 24 / 2014$ ) and the second in two weeks (10/27/2014 to $11 / 11 / 2014)$.

The intervention was performed to adjust the quality and quantity of preparations offered at the CEI. New menus were planned and implemented with the inclusion of selected recipes from culinary websites, books and a manual provided by PNAE. The standardization of per capitas and portions was performed according to recommendations by PNAE ${ }^{10,11}$. Brazilian tables of food composition were utilized to calculate the nutritional value of recipes ${ }^{12,13}$.

The food ingredients used for the meal production at the CEI came from a food service linked to the same Brazilian public educational institution to which the CEI belongs. Thus, at the time of the intervention, recipes were suggested and made according to food availability, which limited the availability and variety of food for the menu planning at times.

The recipes were tested in a Dietetic Technique Laboratory, and adjustments were made in preparation to meet the reference of the PNAE. As the CEI receives a grant from the National Fund for Education Development (Fundo Nacional de Desenvolvimento da Educação - FNDE), the students who were there part-time should receive, at least, meals corresponding to $20 \%$ of the daily nutritional requirements ${ }^{10}$.

The intervention took place for 15 days and evaluators followed the entire process of pre-preparation, handling and food preparation. During this period there were two food handlers involving with the activity and they were followed by two graduate nutrition students. They were oriented to quantificate the crude food, including all the ingredients of the recipes, acoording to per capitas recommended. 
The recipes were cooking and after ready for consumption, we discounted the weight of containers and sum of all preparations characterize the quantity produced. At the time of distribution the portions were standardized in household measure based on the kitchenware available in the CEI. The dishes were portioned and offered for children.

The procedure described in the item "menu evaluation" for the waste-ingestion and clean leftovers evaluation was repeated after intervention. Besides, throughout this process, a follow up was performed with food handlers from the CEI regarding the use of preparation datasheets and portioning of preparations.

\section{Statistical analysis}

Data were entered into Microsoft Excel and analyzed using BioEstat software, version 5.0. The study variables were the AQPC components, waste-ingestion and clean leftovers amounts before and after the intervention. The Kolmogorov-Smirnov normality test was performed and the Mann Whitney test was applied to compare population measures before and after the intervention. The significance level was set at $\mathrm{p}<0.05$.

\section{Results}

During 30 day, divided into two periods of 15 days (before and after the intervention), the CEI was evaluated. The results of the menu evaluation by AQPC showed that there was an improvement in the nutritional and sensory qualities after the performed intervention. A reduction in the occurrence of the following components of the menu was observed: fruit supply, side dish supply, color monotony, presence of sweets, presence of fried foods, presence of sweets associated with fried foods and repetitive cooking techniques. The supply of foods rich in sulfur did not differ before and after the intervention, but its supply was already low before the intervention. Also, after the intervention an increase of the leafy vegetables (and other vegetables) was evidenced (Table 1).

The intervention was instrumental in reducing the amounts of WI/child (from $69.02 \pm$ $11.87 \mathrm{~g}$ to $37.06 \pm 15.57 \mathrm{~g}$ ) and CL/child (from $161.47 \pm 44.12 \mathrm{~g}$ to $35.23 \pm 33.73 \mathrm{~g}$ ), and the minimum values were near zero for the two items evaluated after the intervention, and the maximum values were reduced almost by half for the clean leftovers (Table 2).

However, if the waste-ingestion and clean leftovers are analyzed by percentage there was no significant difference for \% WI (before intervention ranges from 15.57 to 48.97 and after it ranges from 12.50 to $72.86, \mathrm{p}=0.52$ ). For $\% \mathrm{CL}$ the difference between before and after intervention was significant with ranges from 31.55 to 57.77 (before) and it ranges from 0.00 to 49.64 (after), $\mathrm{p}=0.004$ (Table 2).

Table 1. Comparison of percentage occurrence of the AQPC components adapted to the menus of a Brazilian Children's Education Center before and after the intervention in the years 2013/2014.

\begin{tabular}{lcccr}
\hline \multirow{2}{*}{ Items Evaluated } & \multicolumn{2}{c}{ Number of occurrence days } & \multicolumn{2}{c}{ Occurrence $\%^{{ }^{a}}$} \\
\cline { 2 - 5 } & Before & After & Before & After \\
\hline Fruits & 9 & 1 & 60.0 & 6.7 \\
Leafy Vegetables & 8 & 13 & 53.3 & 86.6 \\
Color Monotony & 11 & 1 & 73.3 & 6.7 \\
Foods rich in sulfur & 3 & 3 & 20.0 & 20.0 \\
Sweets & 4 & 0 & 26.7 & 0.0 \\
Fried Foods & 1 & 0 & 6.7 & 0.0 \\
Sweets + Fried Foods & 0 & 0 & 0.0 & 0.0 \\
Vegetable A & 4 & 11 & 26.7 & 73.3 \\
Vegetable B & 3 & 12 & 20.0 & 80.0 \\
Vegetable C & 5 & 8 & 33.3 & 53.3 \\
Presence of a side dish & 8 & 1 & 53.3 & 6.7 \\
Repetition of the main dish cooking techniques & 15 & 2 & 100.0 & 13.3 \\
\hline
\end{tabular}

a The occurrence percentage was calculated considering the number of days evaluation in each period (15 days before and 15 days after the intervention). 
Table 2. Comparative values of waste-ingestion and clean leftovers before and after the intervention in a Brazilian Children's Education Center in the years 2013/2014.

\begin{tabular}{|c|c|c|c|c|c|c|c|c|c|}
\hline & \multicolumn{4}{|c|}{ Before the intervention } & \multicolumn{4}{|c|}{ After the intervention } & \multirow{2}{*}{$\begin{array}{c}\mathbf{p} \\
\text { value }\end{array}$} \\
\hline & Min & Mean \pm SD & Median & Max & Min & Mean \pm SD & Median & Max & \\
\hline Total WI (kg) & 1.44 & $2.16 \pm 0.45$ & 2.1 & 2.84 & 0.65 & $1.68 \pm 0.71$ & 1.70 & 2.6 & 0.030 \\
\hline WI/child (g) & 43.63 & $69.02 \pm 11.87$ & 70.51 & 85.2 & 13.86 & $37.06 \pm 15.57$ & 35.86 & 65.21 & $<0.001$ \\
\hline$\% \mathrm{WI}$ & 15.57 & $29.68 \pm 8.17$ & 27.83 & 48.97 & 10.06 & $35.26 \pm 19.26$ & 29.71 & 72.86 & 0.52 \\
\hline Total CL (kg) & 3.25 & $5.03 \pm 1.46$ & 4.75 & 9.14 & 0.00 & $1.49 \pm 1.27$ & 1.55 & 3.45 & $<0.001$ \\
\hline CL/child (g) & 97.22 & $161.47 \pm 44.12$ & 170 & 240.52 & 0.00 & $35.23 \pm 33.73$ & 33.69 & 113.79 & $<0.001$ \\
\hline$\% \mathrm{CL}$ & 26.22 & $39.55 \pm 7.96$ & 39.67 & 57.77 & 0.00 & $21.01 \pm 17.15$ & 20.67 & 49.64 & 0.004 \\
\hline
\end{tabular}

$\mathrm{WI}=$ Waste-Ingestion; $\mathrm{CL}=$ Clean Leftovers; Min = minimum; Max = maximum; SD = Standard Deviation. Mann Whitney Test, $\mathrm{p}<0.05$.

\section{Discussion}

The results of the first moment indicated that CEI showed failures in quality meals and size portion. Such problems can hinder the fulfillment of nutritional recommendations for this public. Besides, there was no standardization in the quantities and systematic monitoring of the production.

The intervention proposed in this study, focused on the planning and execution of menus in a CEI, provided improvement in the nutritional and sensory qualities of preparations offered for children. Thus, the training actions for food handlers with these issues are important, especially in child-care centers.

The absence of the nutritionist or the lack of trained and poor professional qualification are among factors that may have contributed for these results ${ }^{14-16}$. Then, there is a need of the promote actions to improve the problems identified $^{14}$.

The positive influence of the intervention was also fundamental to assist the fulfillment of objectives of the PNAE, such as meeting the energy and nutrient recommendations for preschool children, forming healthy eating habits, and promoting adequate health, growth and development ${ }^{5}$.

In the first phase, the repetition of the main dish cooking techniques was common. This was also found in the study of the Boaventura et al. ${ }^{1}$ that the more commom applied cooking technique was cooked (or boiling), however the method of frying was employed too. After intervention carried out in the present study, the results demonstrated improvement in the component "cooking techniques" of the main dish. This improvement was possible because during the intervention there was diversification of the protein dish preparation, including cooked and baked preparations, stews and the use of eggs.

The color monotony component was among the most inadequate as found in others studies that used the AQPC method ${ }^{1,6,17}$, but none showed higher values than that found in this study before the intervention, nor lower values than those found after the intervention. Note that it is fundamental to make a thorough evaluation of color in menu planning, as this can decrease the approval of new preparations by consumers, a relevant factor especially when the audience is children, since the visual aspect of food is what draws more attention. Furthermore, this diversity of colors on the plate promotes varied intake of vitamins and minerals $\mathrm{s}^{18,19}$.

As the meal production in the school environment in Brazil is usually performed by food handlers, the decision of the menu of the day is usually made by them in the absence of a nutritionist. The lack of creativity, lack of food or even complacency may be related to the monotony of the CEI menus ${ }^{3}$.

Study performed with 40 child-care in New York found that among people involved with menu planning were cook $(85 \%)$, director $(70 \%)$, registered dietitian $(57,5 \%)$, teachers (45\%), parents $(45 \%)$ and managing committee $(25 \%)^{3}$. Thus, it is necessary to invest in training activities for food handlers, and nutrition education activities involving teachers to encourage appropriate eating behaviors of the children ${ }^{3,420}$. Front of it the performance of nutritionist, at school, is important because this professional can be training and continuous supervision of the all people involved in the proposed activities by PNAE ${ }^{21}$.

In this sense, a study conducted in Chile with 25 teachers and 465 students from Los Andes and 352 control students from San Felipe evaluated the effect of a nutritional intervention, 
structured through educational sessions addressing issues about healthy eating for teachers during five months. A significant improvement in knowledge of teachers was observed, as well as a reduction in consumption of unhealthy foods by students of teachers in the intervention group, showing the importance of integrating knowledge about food at school ${ }^{22}$.

In this study, the only component that has not been modified after intervention was the presence of foods rich in sulfur. This occurred due to limitations related specifically to the supply of vegetables, which compromised the complete preparation of the menu proposed for the intervention. The adequate supply of foods rich in sulfur is extremely important as the gastrointestinal discomfort in preschool children may be associated with excessive intake of foods rich in sulfur $^{23}$.

The only AQPC component that had unsatisfactory results after the intervention was the presence of fruits. This can be explained by not offering dessert on the menu after the intervention, and also due to failures in supply of groceries at CEI. On the other hand, it allowed the exclusion of sweets for dessert. Children prefer sweets and the consumption of these foods is often above recommendations ${ }^{11}$.

However it should be noted that before intervention the parents used to send the sandwich cookies, chips and industrialized beverages for snacks. After intervention period parents were told to send fruit for morning snack, at least three times a week and children received fruit pulp juice at lunch. We recognize that the supply of fruit for lunch is important and before it was reinforced with director and food handlers the fruit presence indication on the menu daily.

Fried foods could be excluded from the menu after the intervention, although this type of preparation showed low occurrence before this period. This is a positive point as the constant consumption of these foods can be considered a risk factor for developing chronic diseases among children ${ }^{24}$. However it is noteworthy that the excess of fat and sugars can be observed some child-care centers ${ }^{3}$.

Before the intervention, the supply of leafy vegetables, and $A, B$ and $C$ vegetables has proven to be greater than those found in other Brazilian studies that evaluated the adequacy of school menus ${ }^{1,4,16}$. After the intervention, the occurrence of all these components on the menu increased, thus providing more varied menus. Even so is more important to conduct nutrition education with children for that the vegetables offered can be effectively consumed ${ }^{3}$.

It is noteworthy that the method used in this study to assess the nutritional and sensory qualities of menus is widely used in Brazilian studies, and the inadequacies found in this study are commonly observed in others studies ${ }^{4,16,25-29}$. The method was extremely important in identifying the flaws in the menu and the definition of intervention strategies to improve the encountered situation.

Besides AQPC, an evaluation of the waste-ingestion and clean leftovers was essential to control the production process and the food waste. The adequacy of the menu and the standardization of preparation datasheets, during the intervention, resulted in a significant reduction in the amounts of rest-intake/child and clean leftovers/child.

The average \%WI found before (29.68) and after (35.26) intervention were lower than in a study ${ }^{4}$ wich found ranges from $29.0 \%$ to $58.0 \%$ and average of the $41 \%$ by children older two years. The difference found in the values by \%WI and waste-ingestion/child can be explained by the fact that the reduction in the amounts of distributed meal were proportionally much larger than the rest of the plate.

It is worth mentioning that in three out of the fifteen days analyzed after the intervention, the clean leftovers were virtually zero, showing that the day planning had been fully achieved and may be a consequence of the handlers' awareness of the importance of per capita standardization, and the use of preparation datasheets and portion control.

Besides the reduction of leftovers and food waste involves an important social issue, as many people live with hunger in the world, it is a management goal of food services due to cost reduction. Another aspect of utmost importance is the control of waste and sustainability ${ }^{4}$.

This study had limitations because there was not a compare group and this fact makes it impossible to know the real influence of intervention on results found in our study.

\section{Conclusion}

The intervention proposed in this study, characterized by the adaptation of the menu and standardization of datasheets, per capita and portioning had a positive influence on the nutritional and sensory qualities of the preparations as well as on the control of clean leftovers and 
rest-intake. The AQPC method was a useful tool to detect failures in the menu and to direct the intervention so as to improve the quality of the menus offered by the CEI.

Considering these results and the lack of intervention studies related to quality of menus offered to communities, the need to conduct further studies to promote healthy eating habits in different environments is suggested.
The importance of a nutritionist in the planning and monitoring of meal production through the development of menus, preparation datasheets and training of handlers is evident. In addition to these actions, nutrition education activities for students, educators and parents are essential to promoting healthy eating habits in the school environment.

\section{Collaborations}

VR Souza and DA Silva worked on the conception and design, on the research and methodology, analysis and interpretation of data, drafting the article, revising it critically and final editing; $\mathrm{AB}$ Ferreira worked on the conception and design, on the research and methodology; JFB São José worked on the conception and design, on the research and methodology, analysis and interpretation of data, revising it critically; EMM Silva worked on the conception and design, on the research and methodology, analysis and interpretation of data, revising it critically. 


\section{References}

1. Boaventura PS, Oliveira AC, Costa JJ, Moreira PVP, Matias ACG, Spinelli MGM, Abreu ES. Qualitative evaluation of menus offered in primary schools in the metropolitan area of São Paulo. DEMETRA 2013; 8(3):397-409.

2. Silva GAP, Costa KAO, Giugliani ERJ. Infant feeding: beyond the nutritional aspects. Jornal de Pediatria 2016; 92 (3 Supl. 1):S2-S7.

3. Erinosho T, Dixon B, Young C, Brotman N, Hayman LL. Nutrition pratices and children's dietary intakes at 40 child-care centers in New York City. J Am Diet Assoc 2011; 111(9):1391-1397.

4. Longo-Silva G, Toloni M, Rodrigues S, Rocha A, Taddei JAAC. Qualitative evaluation of the menu and plate waste in public day care centers in São Paulo city, Brazil. Revista de Nutrição 2013; 26(2):135-144.

5. Brasil. Ministério da Educação (MEC). Fundo Nacional de Desenvolvimento da Educação. Resolução n 38 , de 16 de julho de 2009. Dispõe sobre o atendimento da alimentação escolar aos alunos da educação básica no Programa Nacional de Alimentação Escolar - PNAE. [cited 2013 Jun 20]. Available from: http://www.territoriosdacidadania.gov.br

6. Proença RPC, Sousa AA, Veiros MB, Hering B. Qualidade nutricional e sensorial na produção de refeições. Florianópolis: Editora da Universidade Federal de Santa Catarina; 2005.

7. Harris AD, McGregor JC, Perencevich EN, Furuno JP, Zhu J, Peterson DE, Finkelstein J. The use and interpretation of quasi-experimental studies in medical informatics. J Am Med Inform Assoc 2006; 13(1):16-23

8. Ornellas LH. Técnica Dietética: seleção e preparo de alimentos. $7^{\mathrm{a}}$ ed. São Paulo: Atheneu; 2001.

9. Vaz CA. Restaurantes: controlando custos e aumentando lucros. São Paulo: Metha; 2011.

10. Brasil. Programa Nacional de Alimentação Escolar (PNAE). Referências Nutricionais para o Programa Nacional de Alimentação Escolar Documento Final referente ao Grupo de Trabalho revisado pelo Centro de Referência. Brasília: PNAE; 2009.

11. Barbosa RMS, Croccia C, Carvalho CGN, Franco VC, Salles-Costa R, Soares EA. Consumo alimentar de crianças com base na pirâmide alimentar brasileira infantil. Revista de Nutrição 2005; 18(5):633-641.

12. Núcleo de Estudos e Pesquisas em Alimentação (NEPA). Tabela Brasileira de Composição de Alimentos (TACO). Campinas: NEPA - UNICAMP; 2004. [cited 2013 jun 20]. Available from: http:// www.unicamp.br/ nepa/taco

13. Philippi ST. Tabela de Composição de Alimentos: Suporte Para Decisão Nutricional. 2a ed. São Paulo: Coronário; 2002.

14. Matic I, Juresa V. Compliance of menus with nutritional standards in public and private kindergartens in Croatia. Rocz Panstw Zakl Hig 2015; 66(4):367-371.

15. Melo MNT, Sá RMPF, Melo Filho DA. Sustentabilidade de um programa de alimentação escolar bem-sucedido: estudo de caso no Nordeste do Brasil. Cien Saude Colet 2016; 21(6):1899-1908.

16. Mascarenhas JMO, Santos JC. Avaliação da Composição Nutricional dos Cardápios e Custos da Alimentação Escolar da Rede Municipal de Conceição do Jacuípe/BA. Sitientibus 2006; (35):75-90.
17. Menegazzo M, Fracalossi K, Fernandes AC, Medeiros NI. Avaliação qualitativa das preparações do cardápio, de centros de educação infantil. Revista de Nutrição 2011; 2(24):243-251.

18. Alves FS, Albiero KA. Formação e desenvolvimento de hábitos alimentares em crianças pela educação nutricional. Nutrição em Pauta [online]. 2007 [cited 2013 jun 20]; 15(82). Available from: http://www.nutricaoempauta.com.br

19. Negreiros AB, Costa VS, Cruz MC. Índice de rejeitos em Unidade de Alimentação e Nutrição localizada no município do Rio de Janeiro. Revista Higiene Alimentar 2009; 23(176/177):43-47.

20. Costa EQ. Programa de alimentação escolar: espaço de aprendizagem e produção de conhecimento. Revista de Nutrição 2001; 14(3):225-229.

21. Chaves LG, Santana TCM, Gabriel CG, Vasconcelos FAG. Reflexões sobre a atuação do nutricionista no Programa Nacional de Alimentação Escolar no Brasil. Cien Saude Colet 2013; 18(4):917-926.

22. Montenegro E, Salinas J, Parra M, Lera L, Vio F. Evaluación de una intervención de educación nutricional en professores y alumnos de prebasica y básica de la comuna de los Andes en Chile. Archivos Latino Americano de Nutrición 2014; 64(3):182-191.

23. Reis NT. Nutrição clínica: sistema digestório. Rio de Janeiro: Livraria Rubio; 2003.

24. Casanova M. Prevalência de sobrepeso incluindo obesidade em escolares entre 6 a 10 anos de idade matriculados no ensino público municipal de Balneário Camboriú, Santa Catarina, Brasil [dissertação]. Florianópolis: Universidade Federal de Santa Catarina; 2007.

25. Leal GVS. Consumo alimentar, estado nutricional e nível de atividade física de adolescentes do Projeto Ilhabela/SP [dissertação]. São Paulo: Universidade de São Paulo; 2008.

26. Ricarte MPR, Fé MABM, Santos IHVS, Lopes AKM. Avaliação de desperdício de alimentos em uma Unidade de Alimentação e Nutrição Institucional em Fortaleza-CE. Revista Saber Cientifico 2008; 1(1):158-175.

27. Castro MDAS, Oliveira LF, Passamani L. Resto-ingesta e aceitação de refeições em uma unidade de alimentação e nutrição. Revista Higiene Alimentar 2003; 17(1145):24-29.

28. Oliveira JF, Mendes RC. Avaliação da qualidade nutricional do cardápio do centro de educação infantil (CEI) do município de Douradina-MS. Interbio 2008; 2(1):11-21.

29. Moura PN, Honaiser A, Bolognini MCM. Avaliação do índice de resto ingestão e sobras em uma unidade de alimentação e nutrição do colégio agrícola de Guarapuava (PR). Revista Salus-Guarapuava 2009; 3(1):15-22.

Artigo apresentado em 26/01/2016

Aprovado em 22/03/2017

Versão final apresentada em 24/03/2017 